in $4(18 \%)$ out of 22 patients. Though this did not cause symptoms it nevertheless emphasizes the need to avoid giving gentamicin for minor sepsis. But in life-threatening Gramnegative sepsis in hospital practice we believe gentamicin therapy is the treatment of choice. There is still a tendency to give inadequate doses of gentamicin because of excessive anxiety about its toxicity. Inadequately-treated serious Gramnegative sepsis has a high mortality. The present series shows that vigorous but closely monitored gentamicin therapy gives excellent results without significant toxicity.

We therefore recommend that peak serum concentrations should be measured from the first day of treatment and the dose modified accordingly until values of at least $5 \mu \mathrm{g} / \mathrm{ml}$ or preferably $8-12 \mu \mathrm{g} / \mathrm{ml}$ are achieved. Dosage should be reduced only if concentrations exceed $15 \mu \mathrm{g} / \mathrm{ml}$. Further assays of peak concentrations should be made when the dosage is altered. Trough concentrations as well as peaks should also be measured when there is a change in renal function and at least twice weekly during prolonged therapy. Closer monitoring is necessary during renal dialysis or the oliguric/anuric phase of acute renal failure. The more important function of monitoring is to ensure that adequate peak serum concentrations are reached as soon as possible, provided there is no severe renal dysfunction.

\section{References}

Altermeier, W. A., Todd, J. C., and Inge, W. W. (1967). Annals of Surgery, $166,530$.

Black, J., Calesnick, B., Williams, D., and Weinstein, M. J. (1963). Antimicrobial Agents and Chemotherapy, 3, 138.

Chisholm, G:" D., Calnan, J. S., and Waterworth, Patricia M. (1968). Urinary Tract Infection. Proceedings of 1st National Symposium, ed. F. O'Grady and W. Brumfitt, p. 208. London, Oxford University Press.

Cowan, S. T., and Steel, K. J. (1966). Manual for the Identification of Medical Bacteria. London, Cambridge University Press.

Cruickshank, R. (1965). Medical Microbiology, 11th edn. Edinburgh, $\mathrm{E}$. and S. Livingstone.

Darrell, J. H., and Neale, G. (1972). Prescriber's fournal, 12, 51.

Gatmaitan, B. G., Carruthers, M. M., and Lerner, A. M. (1970). American Fournal of Medical Science, 260 , 90.

Hewitt, W. L. (1971). Fournal of Infectious Diseases, 124, 154.

Jackson, G. G., and Arcieri, G. (1971). Fournal of Infectious Diseases, 124,

S. 130.
Klastersky, J., Genning, C., Monawad, E., and Daneau, D. (1972). Chest,

Marsden, H. B., and Hyde, W. A. (1970). Current Therapeutic Research,

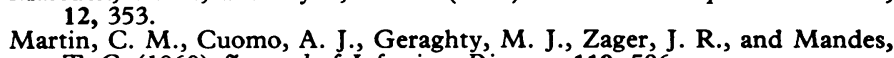
T. C. (1969). Fournal of Infectious Diseases, 119, 506.

Noone, P., Pattison, J. R., and Shafi, M. S. (1973). British Medical fournal, 2, 776 .

Noone, P., Pattison, J. R., and Slack, R. C. B. (1972). Lancet, 2, 1194.

Price, D. J., and Sleigh, J. D. (1970). Lancet, 2, 1213.

Riff, Louise J., and Jackson, G. G. (1971). Fournal of Infectious Diseases, 124, S. 98 .

Wilfert, J. N., Burke, J. P., Bloomer, H. A., and Smith, C. B. (1971). Fournal of Infectious Diseases, 124, S. 148.

\title{
Salt-poor Human Albumin in Management of Nephrotic Syndrome
}

\author{
A. M. DAVISON, A. T. LAMBIE, A. H. VERTH, J. D. CASH
}

British Medical fournal, 1974, 1, 481-484

\section{Summary}

Thirteen patients with the nephrotic syndrome were treated with a high-protein diet, a $0.5 \mathrm{~g}$ sodium intake (equivalent to $1.3 \mathrm{~g}$ sodium chloride), and frusemide in increasing dosage. One became oedema-free with frusemide $240 \mathrm{mg}$ daily, three became oedema-free with frusemide $500 \mathrm{mg}$ daily, and two required a combination of high-dose frusemide and spironolactone. In three there was an appreciable increase in the blood urea, one patient developed hyponatraemia, and in two there was no weight loss. In these six patients infusions of human salt-poor albumin produced a prompt diuresis, loss of weight, and correction of the abnormal biochemical findings. In the seventh severely oedematous patient combined albumin and diuretic therapy led to a loss of $27 \mathrm{~kg}$ in 14 days.

\section{Introduction}

The management of severe nephrotic syndrome is based largely on diet and diuretics, though specific therapy may be used in some forms of glomerulonephritis-for example, conticosteroids in minimal lesion glomerulonephritis. Occa-

Royal Infirmary, Edinburgh EH3 9YW

A. M. DAVISON, B.Sc., M.R.C.P., Registrar, Medical Renal Unit

A. T. LAMBIE, M.B., M.R.C.P., Consultant Physician, Medical Renal Unit A. H. VERTH, Technical Officer, Medical Renal Unit

A. H. CASH, PH.D., F.R.C.P., Deputy Director, Regional Blood Transfusion Centre

sional reponts have mentioned the use of plasma volume expanders. Janeway et al. (1944) undertook the first study of human albumin in this context and concluded that at least in the adult nephrotic patient it had no place; this conclusion was supported by Leutscher et al. (1949). Recent reponts, in which the importance of modern, powerful diuretics have been stressed, have included reference to the occasional use of human albumin (Chamberlain et al., 1966; Garnett and Webber, 1967; Silverberg and Kjellstrand, 1968; Snashall, 1971) but contain little evidence that the introduction of albumin was really necessary or that it was specifically instrumental in inducing a diuresis.

The proposed increase in the national capacity for plasma fractionation (Watt et al., 1972) brings with it the need to consider which patients are likely to benefit from such produots as salt-poor albumin. At the same time there is also a need for data on which to base detailed long-term planning of the national blood resources. We present here the results of a preliminary study to show the existence of a diureticresistant nephrotic syndrome and assess the role of intravenous human albumin in the management of such a condition.

\section{Patients and Methods}

To obtain some idea of the number of patients who might benefit from albumin infusions physicians were invited to refer patients who had oedema resistant to conventional diuretic therapy. In the succeeding 12 months out of a population of $1 \frac{1}{4}$ million 12 patients with the nephrotic syndrome were submitted for possible albumin therapy (table I). A funther patient, admitted for an appendicectomy, was subsequently treated for the nephrotic syndrome.

All patients received a diet containing $22 \mathrm{mEq}$ of sodium 
TABLE I-Clinical Details of Patients with Oedema Resistant to Conventional Diuretic Therapy

\begin{tabular}{|c|c|c|c|c|c|c|}
\hline \multirow{2}{*}{$\begin{array}{l}\text { Case } \\
\text { No. }\end{array}$} & \multirow[b]{2}{*}{ Diagnosis } & \multirow{2}{*}{$\begin{array}{l}\text { Age } \\
\text { and } \\
\text { Sex }\end{array}$} & \multicolumn{2}{|c|}{ Renal Function } & \multicolumn{2}{|c|}{ Plasma Proteins } \\
\hline & & & $\begin{array}{c}\text { Creati- } \\
\text { nine } \\
\text { Clearance } \\
\text { (ml/min) }\end{array}$ & $\begin{array}{c}\text { Protei- } \\
\text { nuria } \\
(\mathrm{g} / 24 \mathrm{hr})\end{array}$ & $\begin{array}{l}\text { Albumin } \\
\left(\mathrm{g}^{\prime} 100 \mathrm{ml}\right)\end{array}$ & $\begin{array}{l}\text { Globulin } \\
(\mathrm{g} / 100 \mathrm{ml})\end{array}$ \\
\hline 1 & $\begin{array}{l}\text { Proliferative glo- } \\
\text { merulonephritis }\end{array}$ & $47 \mathrm{M}$ & 38 & 5 & $2 \cdot 1$ & $2 \cdot 3$ \\
\hline $\begin{array}{l}3 \\
4\end{array}$ & $\begin{array}{l}\text { merulonephritis } \\
\text { Renal amyloidosis } \\
\text { Proliferative glo- }\end{array}$ & $\begin{array}{l}31 \mathrm{~F} . \\
68 \mathrm{~F} .\end{array}$ & $\begin{array}{l}15 \\
20\end{array}$ & 12 & $\begin{array}{l}2 \cdot 3 \\
2 \cdot 0\end{array}$ & $\begin{array}{l}2 \cdot 1 \\
3 \cdot 5\end{array}$ \\
\hline 5 & $\begin{array}{l}\text { merulonephritis } \\
\text { Diabetes mellitus }\end{array}$ & $\begin{array}{l}69 \mathrm{M} . \\
31 \mathrm{~F} .\end{array}$ & $\begin{array}{l}20 \\
20\end{array}$ & $\begin{array}{l}8 \\
11-15\end{array}$ & $\begin{array}{l}2 \cdot 3 \\
2 \cdot 2\end{array}$ & $\begin{array}{l}4 \cdot 2 \\
3 \cdot 2\end{array}$ \\
\hline $\begin{array}{l}6 \\
7\end{array}$ & $\begin{array}{l}\text { Proliterative glo- } \\
\text { merulonephritis } \\
\text { Minimal lesion glo- }\end{array}$ & $16 \mathrm{M}$ & 129 & $10-26$ & $1 \cdot 3$ & $2 \cdot 4$ \\
\hline 8 & $\begin{array}{l}\text { merulonephritis } \\
\text { Systemic lupus }\end{array}$ & $70 \mathrm{~F}$ & 60 & 5 & $1 \cdot 7$ & $3 \cdot 0$ \\
\hline $\begin{array}{r}9 \\
10\end{array}$ & $\begin{array}{l}\text { erythematosus } \\
\text { Renal amyloidosis } \\
\text { Proliferative glo- }\end{array}$ & $\begin{array}{l}31 \mathrm{~F} \\
45 \mathrm{M}\end{array}$ & $\begin{array}{c}15-30 \\
5\end{array}$ & $\begin{array}{l}10 \\
10-15\end{array}$ & $\begin{array}{l}1 \cdot 8 \\
1 \cdot 2\end{array}$ & $\begin{array}{l}2 \cdot 9 \\
4 \cdot 4\end{array}$ \\
\hline 11 & $\begin{array}{l}\text { merulonephritis } \\
\text { Systemic lupus }\end{array}$ & $55 \mathrm{M}$. & 40 & $9-15$ & 1.6 & $1 \cdot 8$ \\
\hline 12 & $\begin{array}{l}\text { erythematosus } \\
\text { Proliferative glo- }\end{array}$ & $37 \mathrm{M}$. & $12-20$ & $8-12$ & $1 \cdot 7$ & 1.9 \\
\hline 13 & merulonephritis & $56 \mathrm{M}$ & 55 & $9-20$ & $1 \cdot 8$ & $2 \cdot 7$ \\
\hline & merulonephritis & $14 \mathrm{M}$ & 100 & $12-20$ & 0.0 & $2 \cdot 9$ \\
\hline
\end{tabular}

(approximately $1.3 \mathrm{~g}$ sodium chloride); those with a blood urea of less than $100 \mathrm{mg} / 100 \mathrm{ml}$ received $90 \mathrm{~g}$ protein daily. Water was not restricted. All patients were fully mobile throughout treatment.

Diuretic therapy was initiated with a single dose of $120 \mathrm{mg}$ frusemide by mouth daily unless the patient was already receiving a higher dose at the time of referral. If after two days this had not induced a loss of weight of at least $1 \mathrm{~kg}$ the dose was increased to $250 \mathrm{mg}$ daily by mouth and finally to $500 \mathrm{mg}$ daily. Potassium supplements were given as required. Before the introduotion of the $500-\mathrm{mg}$ tablet the maximum dose used was $480 \mathrm{mg}(12 \times 40-\mathrm{mg}$ tablets). If this failed to produce a diuresis spironolactone $50 \mathrm{mg}$ four times daily was added to the regimen provided there was no contraindication, such as hyperkaleaemia. After the introduction of spironolactone it was of ten necessary to reduce the potassium supplements. If a satisfactory weight loss had not been achieved after five days of this combined therapy, or if complications developed (table II), albumin infusions were added. Diuretic resistance was defined as a failure to lose $1 \mathrm{~kg}$ daily while on frusemide $500 \mathrm{mg}$, spironolactone $200 \mathrm{mg}$, and a diet containing $0.5 \mathrm{~g}$ sodium daily for a period of at least five days.

TABLE II-Details of Diuretic Therapy and Use of Albumin

\begin{tabular}{|c|c|c|c|c|c|}
\hline \multirow{2}{*}{$\begin{array}{l}\text { Case } \\
\text { No. }\end{array}$} & \multicolumn{2}{|c|}{$\begin{array}{c}\text { Maximum Diuretic } \\
\text { Therapy (.ng) }\end{array}$} & \multirow{2}{*}{$\begin{array}{c}\text { Prime Reason for } \\
\text { Albumin }\end{array}$} & \multicolumn{2}{|c|}{$\begin{array}{c}\text { Weight Loss } \\
(\mathbf{k g})\end{array}$} \\
\hline & $\begin{array}{l}\text { Fruse- } \\
\text { mide }\end{array}$ & $\begin{array}{l}\text { Spirono- } \\
\text { lactone }\end{array}$ & & $\begin{array}{c}\text { on } \\
\text { Diuretics }\end{array}$ & $\begin{array}{c}\text { after } \\
\text { Albumin }\end{array}$ \\
\hline $\begin{array}{r}1 \\
2 \\
3 \\
4 \\
5 \\
6 \\
7 \\
8 \\
9 \\
10 \\
11 \\
12 \\
13\end{array}$ & $\begin{array}{l}240 \\
480 \\
500 \\
500 \\
480 \\
500 \\
500 \\
480 \\
480 \\
480 \\
500 \\
480 \\
480\end{array}$ & $\begin{array}{l}\text { Nil } \\
\text { Nil } \\
\text { Nil } \\
\text { Nil } \\
200 \\
200 \\
100 \\
\text { Nil } \\
\text { Nil } \\
200 \\
200 \\
\text { Nil } \\
\text { Nil }\end{array}$ & $\begin{array}{l}\text { Nil } \\
\text { Nil } \\
\text { Nil } \\
\text { Nil } \\
\text { Nil } \\
\text { Ni! } \\
\text { Rising blood urea } \\
\text { Rising blood urea } \\
\text { Rising hlood urea } \\
\text { No weight loss } \\
\text { No weight loss } \\
\text { Hyponatraemia } \\
\text { Post operative }\end{array}$ & $\begin{array}{r}6 \cdot 8 \\
7 \cdot 0 \\
4 \cdot 5 \\
15 \cdot 5 \\
12 \cdot 2 \\
8 \cdot 3 \\
5 \cdot 4 \\
1 \cdot 2 \\
5 \cdot 0 \\
1.5 \\
1 \cdot 0 \\
0 \cdot 25\end{array}$ & $\begin{array}{r}3.3 \\
6.5 \\
5.5 \\
22.8 \\
9.5 \\
5.2 \\
27.6\end{array}$ \\
\hline
\end{tabular}

Albumin (prepared at the Scottish National Blood Transfusion Association Protein Fractionation Centre) was given as a $15 \%$ solution of salt-poor albumin (sodium content 22 $\mathrm{mEq}$ ), of which $300 \mathrm{ml}$ was infused over a period of 45 minutes provided there was no evidence of cardiac failure. The frequency of infusions depended on the size of the ensuing diuresis.
Throughout the study the patients were weighed daily before breakfast and after emptying the bladder. The 24-hour urinary excretion of sodium and potassium was measured daily, and blood urea, serum creatinine, and electrolyte concentrations were measured three times each week.

\section{Results}

Of the 12 patients referred to us for treatment of their nephrotic syndrome six responded to increased diuretic therapy (table II); one (case 1) lost a satisfactory amount of weight when frusemide was increased to $240 \mathrm{mg}$ daily, three (cases 2, 3, and 4) became oedema-free with up to $500 \mathrm{mg}$ frusemide daily, and two (cases 5 and 6 ) required the addition of spironolactone to achieve adequate weight loss. In all these patients more than $100 \mathrm{mEq}$ of sodium was excreted in 24 hours. No adverse effects were noticed in this group with the exception of postural hypotension in case 3 (fig. 1). In this patient after the introduction of frusemide as a single dose of $500 \mathrm{mg}$ daily there was a weight loss of $4.5 \mathrm{~kg}$; however, severe postural hypotension developed and the dose was altered to $250 \mathrm{mg}$ twice a day and subsequently to $250 \mathrm{mg}$ daily. This was associated with a reduction in sodium excretion and an increase in weight. Administration of $500 \mathrm{mg}$ frusemide by mouth thrice weekly produced a satisfactory weight reduction.

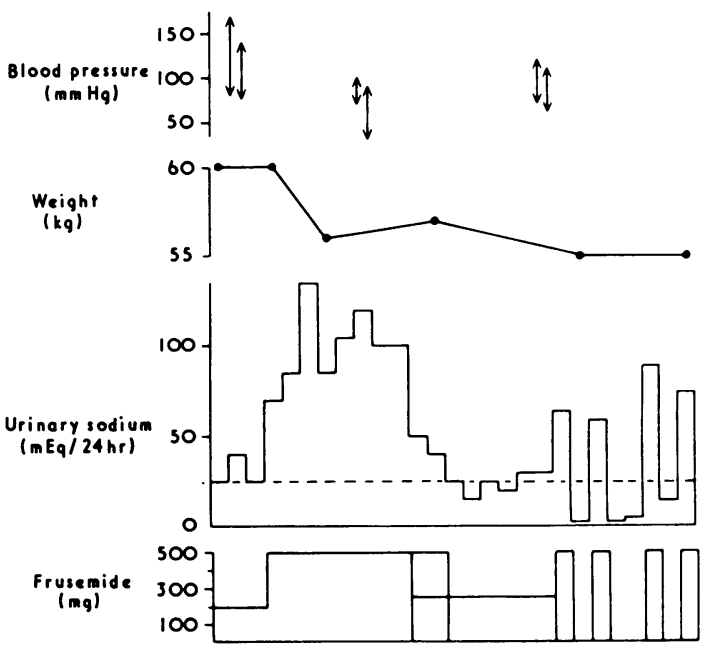

Doys 1111111111111111111111111111

FIG. 1-Case 3, renal amyloidosis. Effect of various doses of frusemide on weight, blood pressure, and 24 -hour urinary sodium. Broken line indicates sodium intake.

Six patients either did not lose weight on the combined diuretic therapy or developed complications which made it impossible to adopt an aggressive diuretic regimen; two (cases 10 and 11) were considered to be truly diuretic resistant, in three (cases 7, 8, and 9) there was an appreciable increase in blood urea, one (case 10) developed hyperkalaemia, and one (case 12) developed severe hyponatraemia.

Two patients on diuretic therapy were given albumin because they failed to lose an adequate amount of weight; this was classified by our criteria as diuretic resistance. In one of these patients (case 11) the urinary sodium excretion exceeded the estimated intake only slightly and his weight remained fairly constant over a period of 19 days in spite of increasing the dose of diuretics. After albumin infusions were started the urinary sodium excretion rose dramatically and he lost $10 \mathrm{~kg}$ in 14 days, with disappearance of the peripheral oedema (fig. 2). A similar response was obtained in case 10 . 

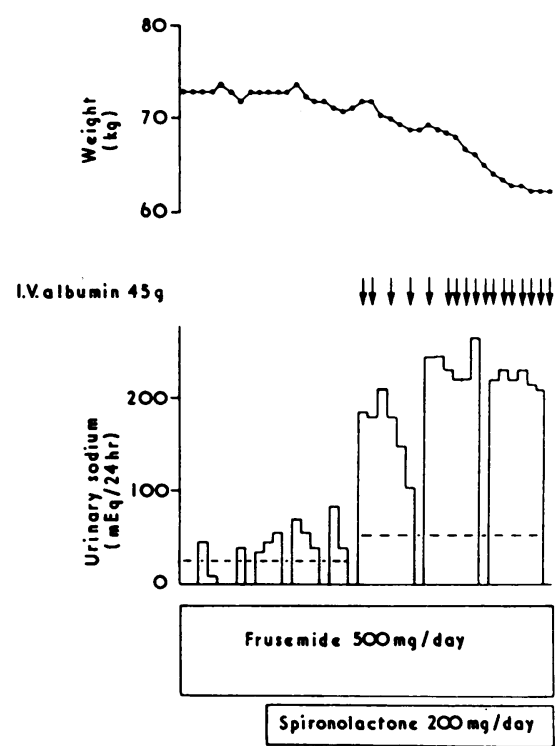

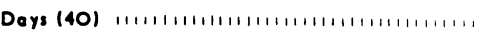

FIG. 2-Case 11, systemic lupus erythematosus. Effect of high-dose diuretic therapy and intravenous albumin on weight and 24-hour urinary sodium. Broken lines indicate sodium intake.

In three patients there was an appreciable increase in blood urea and a fall in plasma sodium during combined diuretic therapy which was producing an adequate weight loss. In one of these patients (case 7; fig. 3) after withdrawal of diuretic therapy and administration of albumin the blood urea fell and the plasma sodium rose. This was accompanied by an increase in weight. The reintroduction of diuretics produced a satisfactory weight loss and the blood urea and plasma sodium returned to normal.

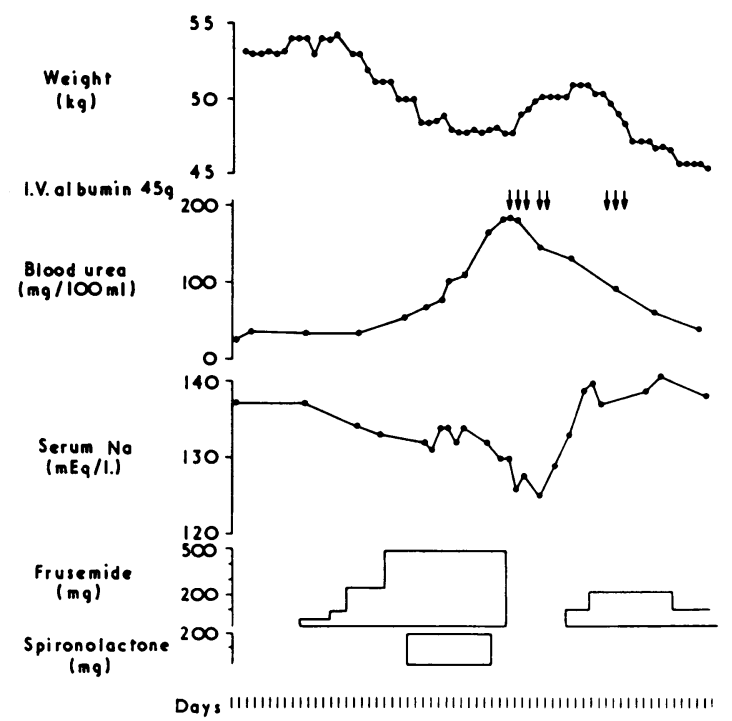

FIG. 3-Case 7, minimal lesion glomerulonephritis. Effect of diuretic therapy and intravenous albumin on weight, blood urea, and serum sodium.

Two patients did not lose a satisfactory amount of weight when receiving $480 \mathrm{mg}$ frusemide daily but in view of raised blood urea and hyperkalaemia they were not given spironolactone. Addition of albumin infusions induced a prompt diuresis and natriuresis.

One patient (case 13) was severely oedematous and had gross proteinuria and hypoproteinaemia. He had recently undergone appendicectomy and was given both albumin and diuretics without delay to reduce the oedema of his abdominal wall. This resulted in a weight reduction of $27 \mathrm{~kg}$ in 15 days accompanied by a fall in blood urea from $190 \mathrm{mg} / 100 \mathrm{ml}$ to $30 \mathrm{mg} / 100 \mathrm{ml}$. During that time the plasma sodium rose from $121 \mathrm{mEq} / 1$. to $137 \mathrm{mEq} / 1$, while urinary sodium exceeded $400 \mathrm{mEq} / 24$ hours (fig. 4).

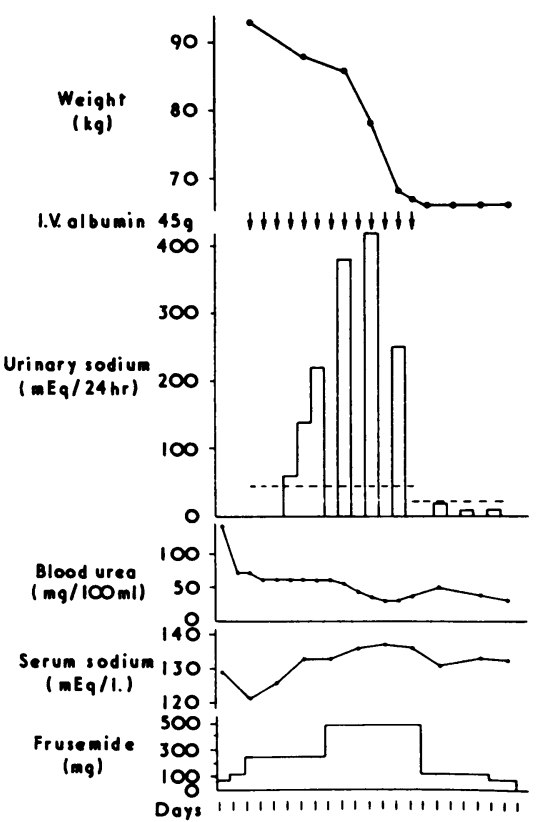

FIG. 4-Case 13, post-appendicectomy. Effects of diuretics and intravenous albumin administered to reduce oedema of abdominal wall. Broken lines indicate sodium intake.

\section{Discussion}

Prolonged proteinuria of more than $5 \mathrm{~g}$ a day results in hypoproteinaemia and development of the nephrotic syndrome. In patients with this syndrome complex and poorly understood physiological mechanisms come into play to maintain the plasma volume, and these compensatory mechanisms may modify the response to diuretic drugs used in the treatment of oedema. The initial response to diuretic therapy in patients with the nephrotic syndrome is often good. Repeated administration of powerful diuretics, however, may further reduce the plasma volume and the glomerular filtration rate (Garnett and Webber, 1967; Jenkes et al., 1970) and in so doing accentuate existing compensatory mechanisms. These changes could account for the development of resistance to diuretic therapy in patients receiving frusemide for prolonged periods and for the rise in blood urea and fall in plasma sodium seen in some of those who continue to respond to the drug. The diuretic resistance seen in our patients appeared to be determined by the severity of the nephrotic syndrome, particularly the severity of hypoproteinaemia, rather than the nature of the disease process.

Infusion of $15 \%$ salt-poor albumin increases the plasma oncotic pressure, which stimulates the reabsorption of water and electrolytes from the interstitial space; the plasma volume increases (Leutscher et al., 1949), the glomerular filtration rate rises, and there is a reduction in the proximal tubular reabsorption of sodium and water (Knox, 1970; Brenner et al., 1969). This results in an increased delivery of sodium and water to the distal nephron which restores the capacity to respond to diuretics such as frusemide. Hyponatraemia developing in the presence of persistent oedema, which has been 
reponted by others (Fichman et al., 1971; Perez-Stable and Materson, 1971), could result from impairment of urinary dilution and also from the aotion of antidiuretic hormone, which is released as a result of plasma volume contraction (Fichman et al., 1971). In some of our patients the addition of albumin infusions was associated with a rapid restoration of the plasma sodium concentration to normal despite a considerable natriuresis at a time when the sodium intake was maintained at a level of only $44 \mathrm{mEq}$ a day (fig. 4).

Several accounts of the treatment of oedema have mentioned the use of albumin as an adjunct to therapy (Chamberlain et al., 1966; Garnett and Webber, 1967; Silverberg and Kjellstrand, 1968; Snashall, 1971) but its precise therapeutic role has not been defined. The early results of albumin therapy in the nephrotic syndrome were disappointing, and this was thought to be due to loss of most of the infused protein in the urine (Janeway et al., 1944; Leutscher et al., 1949). Moreover, albumin was expensive and difficult to obtain, and thus its use was vintually abandoned in favour of other agents, such as mannitol, dextran, and povidone, many of which proved to have undesirable side effects (Rennie, 1956). From this study it appears that albumin infusions must be used in conjunction with effective diuretic therapy, as very little of the sodium and water mobilized from the interstitial space is excreted unless a diuretic is given (fig. 3). This probably accounts for the poor results obtained with albumin infusions before the introduotion of powerful diuretic drugs.

This study suggests that infusions of salt-poor albumin are of value in restoring the capacity of patients with the nephrotic syndrome to respond to moderately large doses of powerful diuretics. It is arguable that a diuresis might have been achieved in such patients by increasing the dose of the drug still funther (Allison and Kennedy, 1971), but prolonged administration of frusemide in large doses is associated in many cases with undesirable complications, such as postural hypotension, hyponatraemia, a fall in the glomerular filtration rate, and a rise in blood urea. Since these are likely to be due to contraction of the plasma volume a good case can be made for adding a plasma expander to the therapeutic regimen rather than increasing the dose of diuretics. In addition, as patients with the nephrotic syndrome have increased total body sodium (Farber and Soberman, 1956; Friis et al., 1970) it seems rational to use a salt-poor albumin concentrate rather than plasma, which contains approximately six times more sodium per gramme of albumin. Of no less impontance is the absence of the risk of transmitting hepatitis when using albumin concentrates. This is particularly relevant to those nephrotic patients being treated by immunosuppressive therapy. Accordingly it appears rational to give infusions of salt-poor albumin to patients with the nephrotic syndrome who fail to achieve a satisfactory diuresis while receiving moderately large doses of frusemide or ethacrynic acid and to those who develop the complications of diuretic therapy mentioned above. In several of our patients it was possible to stop the albumin infusions and stabilize the patient on a lower dose of diuretics once the oedema was reduced (figs. 3 and 4).

Though much of the infused albumin is excreted by the kidney up to $35 \%$ may be retained by the body and will eventually be catabolized, producing essential components for further protein synthesis (Leutscher et al., 1949). This may be of value to the nephratic patient with a negative protein balance and is worthy of further studies. It would also be of interest to study the effect of albumin infusions early in the management of the nephrotic syndrome in an attempt to reduce the length of the inpatient care of these patients.

One of the purposes of this preliminary study was to ascertain whether there was a genuine need for human albumin in the management of patients with the nephrotic syndrome From the results obtained it seems that there are some patients in whom albumin infusions are essential to achieve complete resolution of oedema, and there are others in whom albumin infusion minimize the complications of diuretic therapy. It is likely that as it is introduced to therapeutic regimens more will be required than could be indicated from this group of patients.

The complications of albumin infusions are few. There is a danger of precipitating cardiac failure by the rapid infusion of a plasma volume expander in the presence of diminished renal function, and care must be taken with the elderly or with any patient suspected of having poor cardiac function. We have given more than 150 infusions of albumin with no untoward reactions and consider this to be a safe form of therapy.

This study indicates that infusions of $15 \%$ salt-poor human albumin are of value in treating patients with the nephrotic syndrome who are resistant to diuretic therapy or who are developing undesirable complications such as uraemia or electrolyte imbalance. We suggest that in these circumstances $300 \mathrm{ml}$ should be infused over a period of 45 minutes, provided there is no evidence of cardiac failure, followed by an intravenous injection of $120 \mathrm{mg}$ frusemide to establish a diuresis. The frequency of the infusions will depend on the size of the diuresis, but we suggest that initially they should be given on alternate days.

We are indebted to Dr. J. S. Robson, director of the medical renal unit, and Dr. R. A. Cumming, director of the Edinburgh and South-east Scotland Regional Blood Transfusion Service, for their advice and encouragement, and to Mr. J. Watt and Dr. J. Smith, of the Protein Fractionation Centre, Edinburgh. We are grateful to Professor R. H. Girdwood, Dr. A. Doig, and Dr. L. P. J. Duncan for permission to study patients under their care. The help of Dr. A. MacCuish and Dr. M. Cunningham is gratefully acknowledged.

\section{References}

Allison, M. E. M., and Kennedy, A. C. (1971). Clinical Science, 41, 171 Brenner, B. M., Falchuk, K. H., Keimowitz, R. I., and Berliner, R. W. (1969). Fournal of Clinical Investigation, 48, 1519.

Chamberlain, M. J., Pringle, A., and Wrong, O. M. (1966). Quarterly Fournal of Medicine, 35, 215. Farber, S. J., and Soberman, R. J. (1956). Fournal of Clinical Investigation,

Fichman, M. P., Vorherr, M., Kleeman, C. R., and Telfer, N. (1971). Annals of Internal Medicine, 75, 853.

Friis, T., Nielsen, B., and Willumsen, J. (1970). Acta Medica Scandinavica, $188,65$.

Garnet, E. S., and Webber, C. E. (1967). Lancet, 2, 798.

Janeway, C. A., et al., (1944). fournal of Clinical Investigation, 23, 465.

Jenkes, R. F., Burki, N., and Guz, A. (1970). Clinical Science, 38, 439.

Knox, F. G. (1970). American fournal of Physiology, 218, 819.

Leutscher, J. A., jun., Hall, A. D., and Kremer, V. L. (1949). Fournal of Clinical Investigation, 28, 750.

Perez-Stable, E. C., and Materson, B. J. (1971). Medical Clinics of North America, 55, 359.

Rennie, J. B. (1956). British Medical fournal, 2, 1506.

Silverberg, D. S., and Kjellstrand, C. M. (1968). Acta Medica Scandinavica,

184, 473.

Watt, J. G., Smith, J. K., Grant, W., and Turnbull, C. (1972). Proceedings of the Royal Society of Edinburgh $(B), 71, S 15$. 